\title{
Entrepreneurial assemblages from off the map: (trans) national designs for Tangier
}

\author{
J Miguel Kanai \\ Department of Geography and Regional Studies, University of Miami, 1000 Memorial \\ Drive, Coral Gables, FL 33124-2221, USA; e-mail: miguelkanai@miami.edu \\ William Kutz \\ Graduate School of Geography, Clark University, 950 Main Street,Worcester, MA 01610, USA; \\ e-mail: wkutz@clarku.edu
}

Received 29 September 2011; in revised form 8 March 2012

\begin{abstract}
Poststructuralist perspectives need to be reconciled with political economic readings of urban globalization. One approach complements the other: the enactment of distantiated circuits and the territorialization of flows occur within existing geographies of uneven development while contingently reproducing or reshaping such spatial conditions of possibility. We argue that broadening the realm of critical urbanism is particularly relevant for researching peripheral entrepreneurialisms and their inherent (im) mobilities, conspicuous ambition paired with unavoidable constraints. This paper focuses on Tanger City Center, a landmark redevelopment controversial for its exclusionary designs and troubled inception. Adopting mobile methods with relational perspectives, we retrace the translocal negotiation of this symptomatic assemblage. However, we show that its territorialization cannot be understood apart from the statesponsored remaking of Tangier into an expansive yet also unequal and fragmented city-region. Furthermore, underneath globalist discourse, the assemblage evinces circumscribed (trans)national agency at the planning stage, while subsequent frictions and disruptions punctuate the construction rhythm. Alongside its theoretical thrust, the paper contributes to: (a) the advancement of explicitly urban interpretations of globalization of the Middle East and North Africa, particularly Morocco's emerging neoliberal geographies under King Mohammed VI; and (b) the diversification of narratives of globalization-led urban change by theorizing entrepreneurial predicaments from off the map of global city imaginations.
\end{abstract}

Keywords: policy mobilities, assemblages, postcolonial urbanism, urban redevelopment, Morocco

\section{Introduction}

In this paper we question how large-scale globalization-oriented redevelopments come into being in (formerly) peripheral(ized) cities, weaving narratives that are simultaneously relational and contextual. In its conception and construction the Tanger City Center (TCC) ${ }^{(1)}$ reveals an emergent entrepreneurialism which deploys transposable policies and architectures in conjunction with footloose capital. Adopting network perspectives from mobilities research, we retrace the TCC as an assemblage of city-building technologies from distantiated yet intersecting sociomaterial circuits. Yet, we notice its crucial city-regional context within broader conditions of possibility-geographically uneven development and (multi/cross-)scalar state mediations. Hence, the TCC represents an attempt to profitably harness resources of translocal circulation, but only insofar as one accounts sufficiently for constraints to the entrepreneurial assemblage's ability to climb up hierarchies

${ }^{(1)}$ This is the official name of the project. It uses the name of the city in French. Elsewhere we use the English name of the city, Tangier. 
given its inherited (trans) national peripherality. The TCC is an ambitious albeit challenged and disrupted project problematizing undeterred-flow arguments. Strained planning and construction delays show that mobilities/assemblages/territorializations occur within (and not apart from) friction-filled, fragmentary geographies.

After this introduction, this paper contains four sections and a conclusion. In section 2 we discuss the 'mobilities turn' in urban globalization. We focus on two complementary yet distinct discussions: architectural mobilities and traveling urban policies. We also probe proliferating readings of the assemblage. These capture territorial/relational tensions but also omit the original politicized nuances of French poststructuralism. We conclude that, primarily anchored in network perspectives, mobile/assemblage urbanisms neglect the explanatory power of uneven geographical development.

In section 3 we differentiate the TCC from existing city centers. By locating the TCC in both its immediate surroundings and the broader city-region, we show the scale of intended nodality. Furthermore, we notice several megaprojects implemented strategically throughout Morocco. By reinforcing the premium of economic nodes, these megaprojects rearticulate the national territory according to the neoliberal imperatives of King Mohammed vI. In section 4 we examine the TCC as an entrepreneurial assemblage intersecting economic and semiotic circulations. We retrace actual entanglements, unveiling the prevalence of circumscribed circuits linking the TCC to sites of economic/political/cultural power in Morocco and beyond. These translocal articulations are long-standing; they result not only in dense flow but also in hierarchical ordering. In section 5 we discuss multiple delays, setbacks, and reorientations. Cumulative peripheralization looms large in our explanation: postindependence developmentalism neglected Tangier for decades; contemporary Morocco stands as the Maghreb's most impoverished country; and the region is problematically integrated with global capitalism while simultaneously subject to various other hegemonic influences. Moreover, we argue that frictions are hardly unique to the project but endemic to the territorialization of entrepreneurial assemblages seeking to overcome (or stave off) peripherality.

Our concluding remarks in section 6 emphasize the need to embed urban globalization (im)mobilities within efforts to theorize polyvalent sociospatialities. Off-the-map theories, produced in locations where assumptions of friction-free movement are evidently more problematic, may inform a reconciliation of political economy and poststructural perspectives. Finally, we propose a research agenda on the shapes and meanings of neoliberal urbanism in and beyond Morocco. Upheavals against autocratic regimes throughout the Middle East and North Africa (MENA) have captured global media attention, but it is also pertinent to ask how localized urban entrepreneurialisms may also be subject to democratic reassembly.

\section{The state of the debate and its relevance for Tangier}

The 'mobilities turn' has fueled rich urban research debates (Sheller and Urry, 2006). Unlike earlier rounds of theoretical-methodological arguments (on, for example, place/space or network/scale binaries), such debates have been rooted in explicit concerns-for example, thinking through neoliberal urbanism and its meanings entails problematizations which engage the policy realm while also exhibiting receptiveness to relationality, contingency, performativity, and the mobilization of what Thrift (2004) calls 'transurban' geographies. In fact, Robinson (2011a, page 1088) argues that a panoply of broadly defined FoucauldianDeleuzian poststructuralist perspectives alongside political economy constitutes the dominant approach in a dynamic, expansive literature. Yet, the debate may have reached an impasse, unable to synthesize an inclusive though coherent critical urbanism for the global age and neoliberalism's ostensive ubiquity (Brenner et al 2011; Dovey, 2011). Even rich theorizations seem to caricature rather than engage alternative approaches (Ong, 2011, pages 2-3). 
In this paper we rehearse a dialogue that may elicit further debate and theoretical reconciliation. Our position is undeniably anchored in the central geopolitical economy concern of geographically uneven development, understood as "the composite and dynamic spatio-temporal patterning of socially constructed differences" (Soja and Hooper, 1993, page 182), as well as in the politically mediated multiscalar and cross-scalar state formations (eg, city-regions) implicated in the production, reproduction, and reconfiguration of such differences (Brenner, 2004; Harrison, 2007; 2010; MacLeod and Goodwin, 1999). Yet, we also show that adopting mobile methods (and their poststructuralist underpinnings) can enhance our understanding of geographically uneven development, highlighting its processually contingent and therefore modifiable character.

Calls for nonsedentary research include (a) multisited fieldwork whereby "attention is paid to the connections between one locale and others and the ways that dynamics in one co-construct the others" (Gezon, 2010, page 262), and an ampler (b) analytical sensibility to the transfer of practices (and practices of transfer), which involves following actors and technologies as they travel through the interlocal space of urban policy production, including specialty conferences and seminars, trade fairs, and commercial/exchange delegations (González, 2010; McCann, 2011a; 2011b).

Such heuristics are most meaningful when deployed in correspondence with theoretical underpinnings from mobile/assemblage urbanisms and their intertwined concerns with architectural typologies/city designs and urban policy and planning. Two recent compilations warrant a detailed review as each concerns exemplars (Guggenheim and Söderström, 2009; McCann and Ward, 2011). Guggenheim and Söderström (2009, page 3) argue that "the here in the built environment is always also an elsewhere." They examine the global proliferation of architectural typologies and urban master plans as content shaped within translocal circuits. In such spaces humans (eg, hypermobile architects and migrant construction workers) circulate alongside design ideas and supportive media formats - text and images embedded in cartography, photography, film footage, academic and trade journals, computer-aided design renderings, and websites. Even building materials and ready-made structures are increasingly mobile.

To be certain, Guggenheim and Söderström do not mistake the delineation of circuits for an ultimate explanation. In their reading the mobilities shaping city designs and architectural typologies are not free floating but constituted within the economic and cultural parameters of contemporary capitalist globalization. Convergence/divergence tensions are noteworthy. Frictions occur between globally integrative dynamics (standardized international norms and regulations for construction) and place-specific reassertions of political autonomy and cultural specificity - the latter helping to account for morphological hybridization and the diversification of social uses of the same built typology in different locales. Also, territorially based entrepreneurialisms proliferate amid widespread neoliberalization and deepened interplace competition. Guggenheim and Söderström notice the emergence of globally networked design, construction, and planning firms. These cater to localized demands for (trans)national architecture as symbolic capital [for a study of these dynamics in China see Ren (2011)].

Yet, these arguments overlook how such (spatial) circuits emerge within (and not apart from) existing geographies of uneven development. Rather, the chapters of Guggenheim and Söderström's book are concerned with the specificity of "historical processes that are at play" (2009, page 9). The authors seek to contrast the current neoliberal assembly of globality with preceding modernity/colonialism, thereby tracking (dis)continuities between both eras (eg, King, 2009, pages 31, 38).

A noteworthy exception is Hancock's (2009) study of Tamil Nadu's DakshinaChitra, a 'village museum' exhibiting crafts and 'heartland' buildings. Noticing the recreation of local pasts for global consumption, Hancock advances an explicitly spatial perspective on the 
circulation of the templates of such display. In these templates circuitized heritage architecture is overlain on distinctive geographies of uneven development, "connecting Eurowestern metropoles with colonized and formerly colonized regions, those linking industrial production centers with markets, and those that served as pathways among urban nodes and between those nodes and their rural and suburban hinterlands" (page 102). Moreover, she sketches a space in transition where the museum village and other interstitial 'rural' spaces have been engulfed by and reconstituted within a rapidly changing urban tissue-now a palimpsest of gated communities, ports, industrial estates, information technology campuses, industrial fish farms, and power facilities. Hancock (pages 106-110) falls short of conceptualizing the Chennai-Mamallapuran corridor as an entrepreneurial city-region. Yet, she notes that state and national policies aim for the (trans)nationalization of the corridor, particularly seeking to attract investments in information technology from wealthy nonresident Indians.

McCann and Ward (2011) employ mobile epistemologies, and the specific notion of 'traveling urban policies', to explain the proliferation and geographical variability of entrepreneurial regimes. Critiquing the poorly spatialized 'policy transfer' construct, they forewarn against assuming that networking cities are seamlessly plugged into distantiated circuits. On the contrary, McCann and Ward recognize the onerous work of selectively assembling and territorializing specific policy bundles from circulations at large. They show that so-called 'policy transfers' require actually existing agents (with embodied knowledges and affects) in governmental policy and planning positions, think tanks, public-private partnerships, and professional consultancies, etc. Moreover, drawing from Peck's (2011a) study included in their book, McCann and Ward (2011, page xxvii) recognize that such agents are "organically embedded in distinctive urban political cultures" that vary spatially and historically. They lead highly negotiated and contingent processes to adapt/embed/ territorialize generic approaches to actually existing realms of intervention.

The ensuing chapters of McCann and Ward's (2011) book expand this theoretical framework. Most notably, Massey's (2011) and Robinson's (2011b) essays chronicle the emergence of nonentrepreneurial traveling policies (counterhegemonic, antineoliberal, alter-globalization, solidarity-based, etc) across North-South differences and perceived discontinuities. Massey's engagement with the (now extinct) London-Caracas cooperation plan of former Mayor Ken Livingstone further highlights how relationality is contingently constituted through explicitly territorial politics — or a politics of place (page 3) - and supports the argument that "[i]magining global space as either pre-established closed territorialities or a smooth space of flows is to ignore the grounded and interconnected reality of real politics" (page 12, our emphasis). Moreover, both Massey and Robinson call for increased attention to be given to power relations not only in the territorialization of traveling urban policies but also in the contingent translocal articulation of circuits and the (re)definition of discursive contents.

Yet, Peck (2011a, pages 42-43) reminds us, in a different chapter, that such articulations constitute exceptions rather than the norm and, as in the case of the cut short London-Caracas collaboration, are ever threatened within a landscape of intensified urban competition, 'entrepreneurialized' city managers, and endemic policy mobilities. The transfiguration of progressive cultural policies (mostly implemented by local councils in the UK and European cities between the 1960s and 1980s) into creativity fixes is a case in point. Peck illustrates this transfiguration by looking at contemporary attempts to strengthen Detroit's profile as a creative city. Besides developing a sophisticated list of distinctions between cultural policy experiences within municipal socialism and neoliberal urbanism's prevailing creative approach, Peck argues that the meteoric rise of creativity as policy content is less telling of creativity's own strengths than of the political economic environment of urban policymaking (page 52). Furthermore, the creativity script can easily be overlaid on neoliberal technologies, "thereby relegitimizing and reinforcing both market-confirming practices and regressive social 
redistributions within the city" (page 64). See also Peck's (2011b) case study of Amsterdam and Kanai and Ortega-Alcazar's (2009) comparative research on Mexico City and Buenos Aires, where they found a more heterogeneous and contested blend of progressive cultural policies and creative neoliberalization.

McCann and Ward (2011) recognize (im)mobility tensions between territoriality and relationality, or fixity and fluidity, in the translocal circulation, adaptation, and adoption of urban policy and planning. They tackle such a dialectic with assemblage thinking. This poststructuralist construct, which theorists Deleuze and Guattari originally used to critique psychoanalysis, exhibits an increasing yet equivocal influence among urban researchers (Farías and Bender, 2010; MacFarlane, 2011; Roy and Ong, 2011). Commonly understood as an "alignment of different [sociomaterial] elements" which develop a certain cofunctioning or sympathy (MacFarlane, 2011, page 207), the assemblage denotes both a process and a resulting pattern. McCann and Ward (2011) duly notice that assemblages enact territories while also shaping, reorienting, and reconstituting the wider flows from which they extract their constitutive elements.

Yet, we find this interpretation lacking. MacKenzie (2009, pages 19-22, 32-33, 57) retrieves the French term 'agencement', noting the wordplay between its common meaning of contingent patterning or arrangement (eg, of furniture and appliances in a room) and the implication of agency, even if diffused and entangled. This indicates that the (putting together of an) assemblage is purposeful and truth-making: it is intended to enact material realities - at least the reality which constitutes agents as such, conferring or constraining their capacity to act. Thus, politicized assemblages are subject to contestation. Moreover, they are locatable and hence geographically constituted. We follow this broader understanding, which bridges poststructuralist/relational urbanisms and geopolitical economy. Therefore, we also adopt Allen and Cochrane's $(2007 ; 2010)$ argument that city-making assemblages implicate extralocal political and economic hierarchies. Locally lodged, these interact contingently with more legible forms of territorialized governance, thereby challenging neat delineation.

To summarize, McCann and Ward's (2011) work merits particular consideration for its sophisticated theoretical framework. They address previous work that excludes the cultural, symbolic, and performative in an urban political economy which they see as overly systemic and as having a narrowly construed view of materiality (see the critique by Latham and MacCormack, 2004). Nevertheless, their reading of assemblages betrays deficits in the (politicized, material) spatialization of traveling policy. To be fair to their solidly edited book we notice that approximations to our argument on the relevance of geographically uneven development appear in Massey's (2011) invoking of the asymmetric power geometries of hegemonic globalization and McCann's (2011b, page 101) recognition of the "complex spatialities and power relations of policy transfer". Elsewhere, McCann (2011a, page 121) also notices that policy mobilities are embedded "in particular institutional and political contexts that define a constrained set of potential pathways for action". More attention needs to be paid to the geographical constitution of actually existing circuits in order to better specify the materialities implicated in their base and reference points, directions, and intensities so that the generative extent of such geographies can be theorized.

The shortcomings of network approaches are of particular concern in the current stage of urban globalization research. Debates have moved beyond their North Atlantic origins and even beyond the newly emerged hegemons in the Asia Pacific (Machimura, 2003; Sassen, 2001; Taylor, 2004). As Robinson (2002) puts it, 'global city' hypotheses are now being reexamined from 'off the map'. Assumptions of undeterred access to mobile resources and circulations need to be rethought in order to properly account for inherited conditions of 
peripherality and the degree to which off-the-map entrepreneurial assemblages may be able to climb up urban hierarchies.

The MENA region is a case in point. The Mediterranean Basin functions as a space of dense articulation for much of the region and its cities as well as connecting the MENA region to southern Europe and beyond. Increased maritime trade routes and flows, networked infrastructures, transnational flows of investments and tourists, and cultural exchanges are all part of the MENA region's shifting geographies. Yet urban globalization remains relatively understudied (Stanley, 2005). Recent contributions seek to call attention to "new systems of movement and connection being etched into the cityscapes across the Middle East, [because] these concrete structures tell a story of transformation that has been lost in transition-oriented accounts of Arab political life" (Parker, 2009, page 110).

A solid literature discusses the specificities of Morocco's transition to globalization from its previous experience with postcolonial nationalist development in the second half of the 20th century: the predominant themes being the country's peculiar regime of monarch-centric neoliberalism led by King Mohammed vI; its negotiations with both Islamist and Western influences, which have historically differentiated it from other Arab states; and the redefinition of political-economic elites through corporate, professional, technocratic, and managerial discourses (see, for example, Catusse, 2008; Cohen and Jaïdi, 2006; Zemni and Bogaert, 2006).

But beyond such investigations of "historical processes that are at play" (Guggenheim and Söderström, 2009, page 9), there is an emergent concern with geographies of uneven development (Zemni and Bogaert, 2009). This paper contributes to discussions on new state spaces and city-regional remappings in and beyond Morocco (Bogaert, 2011; Kanai and Kutz, 2011; Planel, 2009). Tangier's particularly tortuous historical geographies, including the fragmentary rule of multiple colonial powers and national neglect during the developmentalist era, are inscribed in both its urban topographies and the topologies that still link it asymmetrically to nodes of power in Morocco, a broadly defined cross-Mediterranean sphere (including the European Union and Arab Gulf states) and beyond. In the sections that follow we show how within this unevenly developed space an entrepreneurial assemblage is enacting the TCC and other paradigmatic sites, thereby territorializing new centralities and fracture lines that may yet elicit further reassembly.

\section{Locating the TCC: a novel node for the emerging city-region}

Projects under the 'city center' (CC) rubric have emerged in major Moroccan cities including Casablanca, Fès, and Tangier. Private developers undertake these government-sponsored mixed-use megaprojects catering to high-end business, retail, tourism, and residential markets. Besides common branding, city centers share several characteristics featured in promotional brochures. The complexes combine high-rise and mid-rise structures arranged along block perimeters. They offer partial street activation through commercial and recreational arcades, but the dominant orientation is inward, evidenced in on-site parking, restricted-access courtyards, and monumental indoor atria contrastive with nondescript facades. Additionally, city center redevelopments are allowed disproportionately higher floor-area ratios than their surroundings, with the aim of increasing land values through intensified premium uses.

With $175000 \mathrm{~m}^{2}$ of floor space and an investment of about 2 billion dirham, the TCC is of a magnitude comparable to other city center megaprojects (Kanai and Kutz, 2011, page 354). Yet, the TCC also exhibits a peculiar location: it is located in the so-called offshore district, a blighted area previously designated to attract industrial foreign investments. Although the TCC is located outside the central business and administrative districts, the project's significance cannot be understood solely in terms of area redevelopment. Rather, the TCC was planned as a novel node within an expansive, multicentered, and transnationally oriented city-region in the making. Its location privileges the integration of a regional industrial 
network over connectivity with adjacent land use and proximity to traditional city centers. Moreover, the TCC designs prefigure an everyday life that departs conspicuously from the current social uses and symbolic appropriations of existing districts.

After Moroccan independence, Tangier experienced rapid suburban expansion. Yet, throughout the mid-20th and late-20th century, city life remained centered on earlier historic overlays and their complex interspersions within the urban core, namely: (a) the medina or precolonial walled city with high population densities and labyrinth-like streets; and (b) the ville nouvelle or colonial district, embellished with Western architectures and linearly regimented by modernist planning (Dalton et al, 1993). In today's Tangier both areas retain central functions, particularly around Grand Socco and Boulevard Pasteur, nodes highly contrastive with the TCC.

The Grand Socco, a combination of Arabic and Spanish meaning 'big market', is adjacent to the medina's southern entrance, where regional tribespeople have marketed their agricultural goods ever since they were allowed to in the mid-19th century by the Sultan of Morocco (Dalton et al, 1993). The symbolic focus lies on the main square, officially named Place du 9 Avril to commemorate the date of King Mohammed v's 1947 speech in support of Moroccan independence (Pennell, 2001). Yet, with most activities taking place off the square, the Grand Socco functions as a key commercial site for the medina and as a node for broader circuits of cultural production and tourism, which seem to increasingly profit from a certain colonial nostalgia.

Eastward streets blend into the ville nouvelle and the commercial and administrative functions clustered along Boulevard Pasteur, which was planned as a linear central district following modernist geometric principles (Zaidi and Chakib, 1982). Designed as the spine of urban growth during the International Zone period (1923-56), the boulevard became the main east-west thoroughfare, intended to steer and order the otherwise uncoordinated urbanization that occurred under the jurisdictional fragmentation of multiple colonial rulers. Moreover, symbolically and functionally, the beautified boulevard connects Place du 9 Avril with Place des Nations and the surrounding cluster of government offices that represent Moroccan state power in the city. Boulevard Pasteur's extension (Avenue de Tan-Tan) then reaches the TCC in the Offshore district, continuing from there to the sprawling eastern suburbs and Cape Malabata.

Until recently, the Offshore district was industrially zoned. But several blocks are being rapidly redeveloped with upscale residential and commercial uses after Tangier's Urban Development Agency (Agence Urbaine de Tanger) designated the Offshore district as a pivotal quarter to articulate metropolitan expansion - the area plan was approved in 2006. More fragmented and car-oriented than the consolidated city districts described above, the Offshore district is best characterized as a transitional area where three highly differentiated zones intersect disjointedly. To the west lies the modern/colonial city with its geometric grid of axial boulevards and densely built blocks of marked uniformity. Further eastward, along the coast towards the Malabata Cape, low-density housing, hotel, and commercial developments appear across a hilly and discontinuous terrain. Industrial land sprawls to the south, interspersed with low-income and informally built housing on environmentally degraded and hazardous hillsides.

Compared with Grand Socco and Boulevard Pasteur, the TCC is far less integrated with its adjacent urban fabric. By defining an inwardly oriented, self-enclosed elite space, the project appears socially exclusionary and rather impervious to political activation through contestatory occupation. Unlike older centers, the TCC is less dependent on the surrounding city. The site's nodality is constituted at the emerging city-region scale, a realm that articulates (and is articulated by) broader mobilities. Therefore, the TCC is strategically located across the street from Tangier's new railway terminus and is also connected to toll roads. Thereby, it demonstrates 
that locational advantage in the city-region is predicated on seamless access to an expansive web of networked transportation and supporting infrastructures (Graham and Marvin, 2001).

Hence, whereas in section 4 we engage further with the distantiated assemblage of the TCC across translocal circuits, it is also possible to deploy assemblage thinking to explore this rapidly territorial development of the Tangier-Tétouan administrative region, interpreting the city-regional thrust as a massive(ly complex) 'assemblage of assemblages' (Bender, 2009; Kanai and Kutz, 2011). Since 1999, $2000 \mathrm{~km}$ of roads and railways have been built to surrounding international air and seaports as well as to planned new towns, free-trade zones (FTZs), and historically unincorporated villages (DS, 2000; 2004; 2008). The Tangier Mediterranean Port (Port de Tangier Méditerranée or Tan-Med) is the major vector for globally oriented city-regional expansion. Located roughly $40 \mathrm{~km}$ east of Tangier, the port has worldclass ambitions, and is expected to service 8 million containers per year by 2016 (TMSA, 2010). In coordination with manufacturing in the FTZs, Tan-Med facilities are intended to harness wealth from the shipping industry passing through the Strait of Gibraltar. Catalyzing city-regional cofunctioning also requires vast subsidiary sociomaterial assemblages (of human bodies and of things, such as car components, to be assembled in maquila-type factories) in order to further profit from the benefits of spatial clustering. For example, massive social housing projects are planned for three new towns in Gzenaya, Mellousa, and Ksar Sghir to accommodate the inflow of rural populations and workers into the consolidating city-region. Within such coordinated expansion, the TCC is planned as a premium node for the newly enacted territorial economy; for example, state-of-the-art office space will cater to commandand-control functions and producer-oriented services, while luxury condominiums and retail space will provide complimentary consumption opportunities for such elite occupations.

Furthermore, the city-regional assemblage of assemblages needs to be located in (and considered constitutive of) the neoliberal state project to create new (trans)national geographies in Morocco. Postindependence developmentalism articulated at the nation-state scale is transitioning to autocratic (monarch-centric) neoliberal globalization (Catusse, 2008; Cohen and Jaïdi, 2006). This shift can be read as an inherently spatial process of territorial restructuring. Transnationally oriented activities (export-oriented manufacturing, attraction of foreign investment, reception of international tourists, etc) become central drivers of urban and regional growth. The Moroccan state proactively invests in networked infrastructures to link and promote premium spaces of growth-for example, the Rabat-Tangier expressway completed in 2005. Hence, economically 'useful' (profit-rendering) territories are increasingly networked within externally oriented circuits, while historically relegated hinterlands are excluded from the development project. This occurs simultaneously and in contradiction to an official discourse of democratic devolution and regionalization: only tenuous state actions redress inherited and newly emerging territorial imbalances (Planel, 2009).

\section{The TCC as a (peripheral) assemblage of (circumscribed) urban globalization mobilities} In this section we adopt assemblage thinking to explore the TCC's (im)mobilities as both an attempt to harness and retain footloose activities and resources in Tangier (high-profile workplaces, tourism revenues, high-end retail, residents with purchasing power, etc) and itself a networked project, which depended for its coming to being on the translocal articulation of various city-building circuits. Therefore, the narrative focuses on retracing such circuits and flows empirically, in order to show that these are both shaped by and constitutive of the geographical uneven development that we in section 3 addressed through multiscalar territorial and state contexts. Also, the topologies laid out here provide an interpretive background for the frictions and limitations discussed in section 5 . 
The TCC needed various forms of regulatory, market, and technical expertise, therefore requiring the enrolment of numerous professionals. Associated with both state and economic power, these actors exhibit high degrees of both career and geographical mobility. The project falls under the remit of the Moroccan Tourism Engineering Corporation (Société Marocain d'Ingénierie Touristique, SMIT). SMIT's mission is to reconvert and reactivate the role of the Moroccan state in tourism planning (MTM, 2005). Created in late 2007, SMIT is a national agency that amalgamates several smaller agencies with circumscribed jurisdictions, including the National Corporation for the Management of Tangier Bay (Société Nationale d'Aménagement de la Baie de Tanger, SNABT). The now extinct SNABT was responsible for coastal development but its projects were largely seen as unsuccessful: with limited economic multiplier effects, fragmentary interventions, and conspicuous environmental impacts. Better funded than SNABT, SMIT exhibits a more professional staff and higher levels of technological support. Yet in order to handle a large portfolio of multiple tourist sites throughout Morocco officials circulate periodically across local offices as they are reassigned to different projects. Short-term travel is also involved in the form of visits to potential investors overseas and participation in international conferences and trade fairs.

Hence SMIT and its projects, including the TCC, epitomize the institutional shifts that have marked neoliberalization since King Mohammed vi's coronation in 1999. The workings of SMIT not only speak to Morocco's touristification but also show how the logics of economic development have moved from centralized governmental ownership and control to a vision of the state as a technical enabler of (trans)national private investment. In the National Debate (Debat National) of 2000, Mohammed vi stated that the Moroccan state could no longer be expected to stand as the "exclusive distributor of wealth" that is "solely responsible for all problems and pitfalls" (Direction de l'Aménagement du Territoire, 2001, page 7). Instead, new policies emphasize the concerted engagement of "local communes, the private sector, civil society and specialists" (page 7). Crucially, the neoliberal rollout was articulated with a dramatic restructuring of regional governance: in 2001 the king broke with the Makhzen's historic nepotism in his appointment of governors. Seven out of nine candidates hailed from outside the Ministry of the Interior (Ministère de l'Intérieur). Whereas these so-called techno-walis (techno-governors) have backgrounds strongly tied to the royal family, their private-sector origin also signifies a growing emphasis on technically oriented and competitiveness-based development (Catusse, 2008; Catusse et al, 2007).

The governor of the Tangier-Tétouan region, Mohammed Hassad, is an emblematic figure. Originally from the Souss, he was educated at the National School of Roads and Bridges (École Nationale des Ponts et Chaussées), one of France's most prestigious grandes écoles. Prior to his 2005 appointment, Hassad headed the Ministry of Public Works (Ministère de Equipement), the Office of Port Operations (Office d'Exploitation des Ports), and Royal Air Maroc; he was also governor of Marrakech (http://www.eib.org/projects/regions/ $\mathrm{med} /$ cooperation/conferences/1st-femip-conference/speakers/mohamed-hassad.htm). Since his arrival in Tangier, he has led the development of the Tan-Med (1 and 2) ports and other globalization-oriented projects, often in collaboration with special-purpose agencies such as SMIT.

SMIT awarded the TCC's master plan and design to a joint team composed of Tangierbased architect Mimoun Mokhtar and Sens Archi, a larger Casablanca-based practice. The latter's proprietor, Jawad el Mesmoudi, has a track record in urban redevelopment and tourism-oriented megaprojects. One of SMIT's senior planners boasted to us that, both at the bidding stage and in final design stage, the project recruited a select group of architects and city designers, bringing together the best of local knowledge and world-class expertise (personal interview conducted on 31 May 2010). The participation of French architects was particularly emphasized in the signification of such global status. 
Construction also entailed foreign participation. SMIT awarded the project to Fadesa, a developer from Spain with investments extending throughout North Africa and Latin America. Upon the bankruptcy of Fadesa, another Spanish group (Inveravante) took over the TCC after thorny negotiations (see section 5). We visited Inveravante's showroom next to the construction site to find that senior staff were based in Casablanca. They visited Tangier only once weekly or for special occasions. We traveled to the Tangier corporate office to meet highly qualified professionals with Moroccan, Spanish, and French backgrounds. Apart from Tangier, they took frequent trips to Rabat, the national capital, and company headquarters in A Coruña, Galicia.

It is noteworthy that this also constitutes the profile of users that the TCC is intended to serve: mobile professionals with demanding travel schedules. While the project is intended to enhance Tangier's overall tourist appeal, business travelers constitute its targeted market niche. SMIT's planners have identified a growing demand for business tourism, for which they report insufficient hotel bed capacity. Most of the city's hotels cluster around the old port and the medina and cater to lower-market niches-such as backpackers and independent travelers making the city their point of entry to Morocco.

The Mövenpick Hotel and Casino is situated 2 miles from the TCC along the Bay of Tangier. In the summer of 2010 this was still the only luxury recreational complex in the region geared to business travelers. We reviewed the scheduled calendar at the hotel's convention center to find numerous events held in Spanish. Firms and organizations from southern Spain appeared prominently on the list. Further inquiry revealed that although the hotel was managed by the eponymous Swiss chain Saudi investors owned it. Reported owners of the casino component include a Jewish Moroccan émigré and a Turkish citizen-which could heighten the misgivings of some commentators in the media about allowing gaming establishments in the kingdom, where citizens are barred from gambling (Iraqi, 2009).

Besides controversy, the casino allows Tangier to capture gaming revenue. Economic development specialists state that this revenue would otherwise run away to a smaller joint in the Spanish exclave of Melilla, less than 200 miles away (personal interviews conducted on 15 December 2009 and 31 May 2010). The rationale of retaining purchasing power, in order to generate employment and fiscal revenue, also guides retail choices for the TCC. The project will contain upmarket retail space, with goods unaffordable for most Tangier residents, but also promises a strengthened city economy.

A SMIT planner commented that wealthy residents and European sojourners often drive to Ceuta, another Spanish exclave located only a few dozen miles away, in order to buy quality goods unavailable in Morocco (personal interview conducted on 28 May 2010). The TCC's business plan shows that commercial components will be managed by the Los Angeles realestate services firm CB Richard Ellis, which has operated in the Moroccan market out of Casablanca since 2005. Within the assemblage this firm constitutes the sole intervening agency that can claim a global (rather than regional) presence. Yet a market analyst informed us that national intermediaries play important roles in the articulation of globally oriented glamorous commercial spaces: mall operators do not negotiate with individual foreign brands directly. Rather, large Moroccan operators assemble franchise bundles for joint countrywide distribution (personal interview conducted on 2 June 2010).

The residential component is also intended for an elite (trans)national public. Inveravante's commercial strategy for TCC condominiums is aimed explicitly at highly mobile buyers, including part-time residents and seasonal visitors. Before the 2008 economic crisis, initial schemes focused on European buyers of second homes and investment properties. The project's commercial website has English, French, and Spanish versions available (http://www.tangercitycenter.ma). Nevertheless, after assuming control of the project, Inveravante added a new focus by marketing to Moroccans residing in major European cities (eg, Paris, Amsterdam, Brussels). In May of 2010 the TCC was taken to the seventh 
edition of the Moroccan Real Estate Fair in Paris (Salon Immobilier Maroccain à Paris, SMAP IMMO). This massive fair featured more than 140 exhibitors, representing close to 55 cities from all across Morocco, and reportedly received a record of over 50000 visitors (Challenges, 2010; SMAP IMMO, 2010).

Inveravante ran a booth in Tangier's section. It showcased a scaled model for the project (1:750), promotional videos, and a touch screen for visitors to interact with the project's website. We interviewed a sales representative after the fair, who reported that participation in SMAP IMMO was a resounding success - a significant portion of condominium units had been presold or booked (personal interview conducted on 1 June 2010). Her optimism was not about the clear financial boost to the project while it was still under construction but due to her 'growing confidence' that the TCC would reach completion. A previous hiatus had proven particularly uncomfortable given the number of speculative condominium projects that are never completed in Tangier. The TCC also participated in the 2011 edition of the fair. For 2012, SMAP IMMO extended to Marseille, Brussels, Amsterdam, Milan, and Barcelona.

Commentary is warranted regarding the use of promotional architectural imagery. Many have argued that flagship buildings and structures are increasingly spectacularized to symbolize (and perform) the global relevance and ambitions of cities. Resorting to iconic design and easily recognizable architectural typologies (eg, the high-rise tower and increasingly the mixed-use integrated urban megaproject) is a well-known strategy. But spectacularization extends to image and discourse production during (and even by means of) construction (Greenberg, 2003; Lehrer, 2003; Ong, 2011).

The TCC is clearly a more modest example than the cases which are studied in the literature. Yet the TCC assembled a panoply of architectural drawings, photographical images of 'model' users, and narratives of urban modernization and upgrading. These appeared repeatedly on the project's website, on printed materials, and on the perimeter fence of the construction site. Models with fair skin and hair and light colored eyes appear mingled with darker phenotypes in work situations, as well as shopping and relaxing at home. All images portray young individuals and nuclear families, with at most two children, in nondescript Western clothes with no sign of religious or ethnic affiliations. Whereas some units include a Moroccan-style living room, no images depict floor seating or other possible traditional uses of space. Computer-generated images portray the complex fully illuminated with impressive sunsets in the background. These can also be seen above the retail center's glass dome, contrasting with the interior glitz of neon, metal, and marble. Photographs exhibit the units' high-quality finishings. After the initial developer's bankruptcy and the postponement it caused, Inveravante has been posting monthly update pictures starting in early 2010 . These have documented ground breaking, the laying of foundations, and the overall construction progress.

\section{Limitations and delays: friction-filled, uneven geographies as explanation}

Analysts of entrepreneurial assemblages need to look beyond the networks that articulate projects translocally if they are to avoid unwarranted conclusions of undeterred mobility. Friction is a helpful concept to probe how territorializations occur. Friction may entail resistance and contestation but also implies messy and surprising encounters across distanciated difference. These result in unstable, awkward, and unequal interactions that may nevertheless generate creative responses (Tsing, 2005, page 4).

Representations of the TCC circulated beyond the developer's curatorial efforts. Tangier's forum on skyscrapercity.com is telling (http://www.skyscrapercity.com/forumdisplay. php? $\mathrm{f}=1708$ ). The thread on the TCC is the most active one - 679 entries and almost 120000 views between August 2006 and February 2012. We reviewed valid entries (largely written in English and French but also in Arabic, Spanish, and Dutch/Flemish) indicating various 
degrees of support. Several commentators posted their own pictures and visuals, selectively emphasizing either strengths or weaknesses in terms of location and design quality.

In the initial period after early drawings of the TCC were unveiled commentators were enthusiastic about the "great project" (entry number 3, November 2006) and a Tangier "changing fast into a new international quality modern city" (entry number 23, August 2007). Most entries reproduced Inveravante's images and technical specifications, and one contributor expressed excitement at the "first impression" that would be experienced by visitors arriving on the high-speed train from Rabat promised to be built by 2014 (entry number 38, December 2007). Yet, the mood of the forum shifted after changes in corporate ownership and construction delays. Questions were posted regarding the progress of the seemingly "ghost project" (entry number 150, November 2008), and some people commented on Tangier's endemic real-estate speculation.

Opinions split as Inveravante made new inroads. Some continued praising the TCC, as, for example, the "new medina gate for the new city" (entry number 325, December 2010), and Tangier's tallest building, first to surpass the 20 -story mark (entry number 434 , May 2011). Others decried the mocheté (ugliness) of massive white walls of concrete and the heavy institutional look, reminiscent to some of medical centers in the United States (eg, entry numer 278, August 2010; entry number 390, March 2011). Inveravante was suspected of downgrading the design in order to cut costs (entry number 373, March 2011). Additional criticisms referred to: the bias towards high-rise structures, which was no different from the mistakes that had been made throughout Europe for decades (entry number 186, December 2009); the decision to add structural density in a peripheral quarter (entry number 425, April 2011); and the deepening of sociospatial segregation that the TCC implies for a city already exhibiting high levels of inequality and uneven infrastructure provision (entry number 191, December 2009).

Support for the project surged again after the announcement of a definitive completion date (late 2012) and the announcement that the megaplex cinema planned for the TCC would be managed by Mégarama, a French chain owning multiple complexes throughout Morocco. Yet criticisms also continued and one user expressed a concern with high-rises 'mushrooming' and Tangier increasingly looking like an overbuilt Malaga and Benidorm in Spain (entry number 554, September 2011).

The entries represent no more than individual perceptions and opinions. A lack of additional data on the contributors' profiles prevents attempts at any further generalization. Nevertheless, the mere existence of such a (trans)national forum with perspectives clearly other than those associated with the assemblage speaks to the need for a broader analytics to deal with the frictions implicated in the project's territorialization. Moreover, beyond aesthetic arguments and alternative representations, friction should be expected in the site's materialization.

Faulconbridge (2009) argues that the putting 'in place' of architectural blueprints entails an adaptation to localized regulatory schemes (eg, zoning and construction norms) and a cultural translation of the original design to the inhabitation practices of the users and publics of the intended construction. Both processes are clearly open to politicization, which gives us grounds to claim that insofar as the territorialization of entrepreneurial assemblages can be associated with the emergence of hybrid citizens and spaces of neoliberal exception (Ong, 2006) it also provides instances for the reassembly of globalist urban forms according to alternative claims. This may be equated to the beginning of democratic accountability.

Whereas we were unable to detect evidence of more direct contestation regarding the TCC (which could have buried in, for example, municipal minutes and other governmental documents simply unavailable to us), our investigation showed that certain modifications to the original layout were, indeed, required. SMIT planners reported that the 'Barcelona 
model', which was the original inspiration, had to be adapted to Tangier's local climate; outdoor components were reduced or altogether scrapped. Our interviewees emphasized that every redevelopment initiative in Tangier requires local permits and communal approval (eg, a development project in the Charf Hills adjacent to the TCC was abandoned due to local opposition).

While not directly accountable to the local electorate, SMIT has undertaken several initiatives to improve public space along the beach, including a large skateboard facility and other free recreational facilities. Beautification is compatible with the overall mission to increase touristic appeal, yet the interventions appear more concerned with providing local populations with public facilities and a sense of inclusion than with attracting foreign investment through the brokerage of profitable real-estate deals.

Setbacks and interruptions may have confounded the management of localized social expectations but their causes seem to lie elsewhere. In the previous section we delineated how the TCC came into being within specific translocal circuits with ostensible (trans) national circumscription. What follows is an account of how such peripheral positioning (contingently) translated into disruptions and shortcomings. This path dependency is also detectable in the assemblages of other entrepreneurial projects.

Inveravante's takeover of the TCC after the previous developer's bankruptcy is telling. As a large multinational conglomerate, Inveravante is in the process of carrying out multiple investments throughout Morocco. Anfa Place, a flagship urban megaproject in Casablanca, stands out amongst these. The TCC and Anfa Place networks show partial overlaps: for example, CB Richard Ellis and the architectural firm Sens Archi are participating in both projects. Yet, Anfa Place has also enrolled Foster + Partners as coarchitects, arguably the world's most successful starchitectural practice (McNeill, 2005). This major difference between the projects can be explained by the much higher land values and real-estate prices that the Casablanca market can bear. Development plans and investment programs under King Mohammed vi lifted Tangier out of its long-standing postindependence decline. Yet, the urban economy lags far behind that of Casablanca, Morocco's preeminent city-region, now also being reshaped according to the imperatives of neoliberal globalization.

Furthermore, Inveravante's engagement also reflects the complex circuits whereby capital, construction, and urban planning technologies flow from Spain to (neighboring, formerly colonized) Morocco. These circuits are themselves relationally constituted by multiple back-and-forth (im)mobilities between both sides of the Strait of Gibraltar, which also include unregulated migration, smuggling, security, sex tourism, and child exploitation as well as state-centric attempts to manage them.

In early 2006 the TCC contract was initially awarded to a group led by Fadesa, a large Spanish developer. Thereby, the project was integrated into the firm's extensive network of construction expertise and financing capacity. But it was also exposed to the risks associated with the highly speculative and financialized real-estate and construction sectors of Spain in the early 2000s. Soon after Fadesa won the bid, it merged with Martinsa. Thereby, numerous real-estate assets shifted from being privately owned (by the Jove Capellán family) to being held by the largest publicly traded real-estate group listed in the Madrid stock exchange. However, amid economic recession and a particularly sluggish real-estate market, less than a year later the Martinsa-Fadesa merger resulted in another record: the largest corporate bankruptcy in Spain's history (Durán, 2008). As the bankrupted group was divested of Moroccan positions, work at the TCC was halted for over a year. The project would recommence only under Inveravante, a new holding company created by a familiar figure: Manuel Jove Capellán, Fadesa's original founder, former president, and majority shareholder until the takeover. 
We interviewed corporate representatives about Inveravante's decision to reengage with the TCC. They mentioned Jove Capellán's affective allegiance to Morocco. In an interview with Madrid-based $A B C$ daily, Jove Capellán himself talks about the country as his "second home in the world" (after Spain), Rabat being the only foreign city where he owns a private residence and which he often travels to with his family (MP, 2009). Yet, other media reports (from both Spain and Morocco) portray much more complex, negotiated, and secretive entanglements between the investor and the monarchic neoliberal regime.

For Inveravante the TCC is part of a major portfolio of investments. While diversified across sectors and locations, these investments nevertheless rest on awarded contracts for urban development and energy supply (MP, 2009; Rodríguez, 2008). Smooth relations with governmental actors, including the continuity of Inveravante's favored projects such as the TCC, are ostensibly critical for profitability. On its part, the Moroccan state relies on powerful foreign investors such as Inveravante to enact (trans)national designs.

Therefore, whereas frictions and constraints relationally shaped within unevenly developed geographies took the specific, localized form of a protracted halt to the construction of the TCC, they can be thought of in terms of a much more pervasive predicament for peripheral (and for well-established yet increasingly challenged) entrepreneurial assemblages. Here, again, mobile urbanism and assemblage thinking help us to extricate and bring to the fore complex geopolitical economic entanglements.

Extending the detailed analysis to Inveravante's other projects would exceed the scope of this paper. Yet the following vignette illustrates the point above: Jove Capellán has been publicly honored by King Mohammed vi for his various enterprises in Morocco since the early 2000s, including social housing in Rabat and a luxury tourist resort in Saida. However, an incident in 2009 is symptomatic of potential volatility in the partnership. Construction in Casablanca's Anfa Place was interrupted for two weeks in September after the king himself was reported to visit the site and order an immediate cease of activity. None of the parties involved gave official reasons for the decision or for its later reversal. The Moroccan press has speculated on: governmental discomfort with the handling of the site's debris and noise in such an upscale neighborhood; concerns about future sales of alcohol from an adjacent mosque and villa owned by influential Saudi nobility; and even lingering discontent with the Jove Capellán family's past sale of its Moroccan projects to Fadesa (Cembrero, 2009; Slaoui, 2009).

\section{Conclusions}

Construction proceeded as planned at the TCC site as we finalized this paper. Inveravante announced an expected completion date of late 2012 for the first phase and a 2013 grand opening (http://www.tangercitycenter.com/admin-tcc/images/presse/16.pdf). Further research on social uses will be possible once the site is inhabited. The limits to the assemblage's actual capacity to 'put Tangier on the map' of urban globalization may become more evident when globalist tropes and promises largely materialize in economic activities with (trans)national circumscription. Politicized contestation may also heighten when expected sociospatial inequalities are actually experienced or lived in and around the materialized setting. Creative spatial practices may result in nonconforming, or even illicit, uses of the space by those not catered to by planning. Yet, rather than speculating, we leave these issues for future research on the potential reassemblage of the TCC beyond entrepreneurial intent. Our final remarks are intended to synthesize work thus far completed, highlighting broader implications to think through urban globalization from 'elsewheres' such as Tangier, off the map of global city imaginations.

We have shown that conceptualizing the TCC as an assemblage of explicit entrepreneurial character helps to retrace translocal articulations of multifarious agency reaching and 
(re)shaping the project. In our reading these findings stand as analytically enriching rather than at odds with the emergent city-regional dynamics that provide a territorialized explanatory context for the project's intentionality. We have also embedded the TCC's mobilization of technologies and professionals within the production of Morocco's novel (trans)national geographies under monarchic neoliberalism. This illustrates claims of circuitized citymaking occurring in a constitutive "three-dimensional mosaic of increasingly reflexive forms of governance, shaped by multi-directional forms of cross-scalar and interlocal policy mobility" (Peck and Theodore, 2010 page 170).

By linking project-specific outcomes (setbacks and delays) to Tangier's circumscribed, path-dependent reach within (trans)national spheres, we have advanced an empirically grounded critique of urban globalization narratives that are oblivious to the constitutive role of geographically uneven development in the assemblage and territorialization of city-making mobilities. Brenner et al (2011) make the point theoretically, steering attention to what they call the 'context of contexts'. Although we have embraced poststructuralism as a means of dispelling possible nuances of a priori structural overdetermination, the paper stands as a cautionary note on invocations to (im)mobility as a dematerialized spatial metaphor.

The coming to being of circuits, circulations, travels, assemblages, and deterritorializations/ reterritorializations is filled with contingency but there is much to be gained by engaging these processes within their constitutive geographies. Much work lies ahead in order to properly imbricate the research sensibilities of the 'mobility turn' with urban globalization studies and broader efforts to reframe sociospatial theory (Brenner, 2009; Jessop et al, 2008) -we expect substantial discussions between those like us focusing on the constitutive materialities of geographically uneven development and those emphasizing topological relations of causality predicated on, for example, presence and reach (Robinson, 2011b).

We have constructed arguments from an embattled Tangier redevelopment as a response to Roy's (2009) call for new geographies of theory, rethinking urban globalization from the Global South. Friction may be more easily ignored by globalist discourses from nodes supported by centripetal infrastructures and technologies. Theorizing from 'ordinary' challenged cases helps to highlight the efforts required to bend real-and-imagined urban hierarchies. The TCC's predicaments may resonate with multiple other emerging entrepreneurialisms. More established cities may also seek to stave off the destabilization and loss of centrality threatened by efforts from the likes of Tangier.

By focusing on friction and openings for resistance in a case of seeming techno-economic resolution, we have called for increased attention to the politics of urban globalization in the MENA region. During the Arab Spring, media coverage showed cities playing constitutive roles in extraordinary social mobilizations against autocratic regimes conniving with global capital. Yet, more research is needed on possible contestations about neoliberal urbanism embedded within rapidly changing everyday urban life. Discursive struggles are worth following: whereas entrepreneurialism may elicit affective empathy and political support, invoking national and territorial pride, proliferating online forums such as skyscraper.com confound attempts at monolithic symbolism.

We close with a disclaimer and a specific focus for future research. While supported with systematic archival and online media research as secondary sources, our primary fieldwork was limited to Tangier and Casablanca due to our own mobility constraints. Successive engagements with transnationally oriented urban projects may benefit from collaborations with researchers better able to access the multiple sites implicated in their assemblages. Future TCC residents (both permanent and seasonal) from the Moroccan diaspora interest us particularly. More research is needed on the financial, logistic, and affective connections whereby they purchase property in the homeland. Various studies show the roles that these actors play in processes of democratization and political reform at the national level, but their 
positioning vis-à-vis specific urban issues is still widely unknown. Elucidating this may help to enact solidarity assemblages with other less fortunate city-regional inhabitants and would support a more inclusionary politics of urban(-global) living.

Acknowledgments. The University of Miami's College of Arts and Sciences funded fieldwork for this paper. Kanai presented an earlier version at MOVE international seminar, 6-8 June 2010, University of Neuchâtel. Generous comments from Eugene McCann, Ola Söderström, and this journal's anonymous reviewers helped us to refine our arguments. The usual disclaimer applies.

\section{References}

Allen J, Cochrane A, 2007, "Beyond the territorial fix: regional assemblages, politics and power" Regional Studies 41 1161-1175

Allen J, Cochrane A, 2010, "Assemblages of state power: topological shifts in the organization of government and politics" Antipode 42 1071-1089

Bender T, 2009 "Post script: reassembling the city—networking and urban imagination", in Urban Assemblages: How Actor-network Theory Change Urban Studies Eds I Farías, T Bender (Routledge, London) pp 303-324

Bogaert K, 2011, "New state space formation in Morocco: the example of the Bouregreg Valley" Urban Studies 49 255-270

Brenner N, 2004 New State Spaces: Urban Governance and the Rescaling of Statehood (Oxford University Press, Oxford)

Brenner N, 2009, "A thousand leaves: notes on the geographies of uneven spatial development", in Leviathan Undone? Towards a Political Economy of Scale Eds R Keil, R Mahon (University of British Columbia Press, Vancouver) pp 27-49

Brenner N, Madden D, Wachsmuth D, 2011, "Assemblage urbanism and the challenges of critical urban theory" City 15 225-240

Catusse M, 2008 Le temps des entrepreneurs: Politique et transformations du capitalisme au Maroc (Maisonneuve et Larose, Paris)

Catusse M, Cattedra R, Janati M, 2007, "Decentralization and its paradoxes in Morocco", in Cities of the South: Citizenship and Exclusion in the 21st Century Eds B Driesken, F Mermier, H Wimmen (Saqi Books, London) pp 113-135

Cembrero I, 2009, "Rabat investiga a un promotor español cuya actividad podría 'ofender' a una mezquita" El País 18 September, http:// www.elpais.com/articulo/economia/Rabat/investiga/promotor/espanol/cuya/ actividad/ podria/ofender/mezquita/elpepueco/20090918elpepueco_13/Tes

Challenges, 2010, "50 000 visiteurs pour le SMAP IMMO à Paris", http://www.challenges.fr/immobilier/actualites/evenements/20100608.CHA4794/50_000_ visiteurs_pour_le_smap_immo_a_paris.html

Cohen S, Jaïdi L, 2006 Morocco: Globalization and Its Consequences (Routledge, New York)

Dalton R, Pearson R, Barrett H, 1993, "The urban morphology of Tangier", in Tanger: Espace, Economie et la Société Ed. M Refass (Université Mohammed v, Université Abdelmalek Es-Saâdi, Tangier) pp 113-123

Direction de l'Aménagement du Territoire, 2001 La Charte Nationale de l'Aménagement du Territoire Editions Okad, Ministère de l'Aménagement du Territoire, de l'Urbanisme, de l'Habitat et de l'Environnement, Rabat

DS, 2000, “Annuaire Statistique Régionale Tanger-Tétouan” Ministère de la Prévision Economique et du Plan, Délégation Régionale de Tanger-Tétouan, Rabat

DS, 2004, "Recensement Général de la Population et de l'Habitat", Haut Commissariat au Plan, Direction de la Statistique, Rabat

DS, 2008, "Monographie de la Région Tanger-Tétouan", Haut Commissariat au Plan, Direction de la Statistique, Tangier

Dovey K, 2011, "Uprooting critical urbanism" City 15 347-354

Durán Y, 2008, "Martinsa-Fadesa, del parqué a la suspensión de pagos ” El País 18 July, http://economia.elpais.com/economia/2008/07/18/actualidad/1216366380_850215.html 
Faulconbridge J R, 2009, “The regulation of design in global architecture firms: embedding and emplacing buildings" Urban Studies 46 2537-2554

Farías I, Bender T, 2010 Urban Assemblages: How Actor-network Theory Changes Urban Studies (Routledge, New York)

Gezon L, 2010, "Khat commodity chains in Madagascar: multi-sited ethnography at multiple scales", in Environmental Sciences: Methods and Research Design Eds I Vaccaro, E Smith, S Aswani (Cambridge University Press, Cambridge) pp 238-265

González S, 2010, "Bilbao and Barcelona 'in motion': how urban regeneration 'models' travel and mutate in the global flows of policy tourism" Urban Studies 48 1397-1418

Graham S, Marvin S, 2001 Splintering Urbanism: Networked Infrastructures, Technological Mobilities, and the Urban Condition (Routledge, New York)

Greenberg M, 2003, "The limits of branding: the World Trade Center, fiscal crisis, and the marketing of recovery" International Journal of Urban and Regional Research 27 386-416

Guggenheim M, Söderström O, 2009 Re-shaping Cities: How Global Mobility Transforms Architecture and Urban Form (Routledge, New York)

Hancock M, 2009, "DaksinaChitra: translating the open-air museum in Southern India", in Re-shaping Cities: How Global Mobility Transforms Architecture and Urban Form Eds M Guggenheim, O Söderström (Routledge, New York) pp 101-122

Harrison J, 2007, "From competitive regions to competitive city-regions: a new orthodoxy but some old mistakes" Journal of Economic Geography 7 311-332

Harrison J, 2010, "Networks of connectivity, territorial fragmentation, uneven development: the new politics of city-regionalism" Political Geography 29 17-27

Iraqi F, 2009, “Tourisme : Casinos, le dernier tabou?" TelQuel Online 28 September, http://www.bladi.net/tourisme-casinos-le-dernier-tabou.html

Jessop B, Brenner N, Jones M, 2008, "Theorizing sociospatial relations" Environment and Planning D: Society and Space 26 389-401

Kanai M, Kutz W, 2011, "Entrepreneurialism in the globalizing city-region of Tangier, Morocco" Tijdschrift voor economische en sociale geografie 102 346-360

Kanai M, Ortega-Alcazar I, 2009, "The prospects for progressive culture-led urban regeneration in Latin America: cases from Mexico City and Buenos Aires" International Journal of Urban and Regional Research 2 483-501

King A D, 2009, "Notes towards a global historical sociology of building types", in Re-shaping Cities: How Global Mobility Transforms Architecture and Urban Form Eds M Guggenheim, O Söderström (Routledge, New York) pp 21-42

Latham A, McCormack D, 2004, "Moving cities: rethinking the materialities of urban geographies" Progress in Human Geography 28 701-724

Lehrer U, 2003, "The spectacularization of the building process: Berlin, Postdamer Platz" Genre $36383-404$

McCann E, 2011a, "Urban policy mobilities and global circuits of knowledge: toward a research agenda" Annals of the Association of American Geographers 101 107-130

McCann E, 2011b, "Points of reference: knowledge of elsewhere in the politics of urban drug policy", in Mobile Urbanism: Cities and Policy-making in the Global Age Eds E McCann, K Ward (University of Minnesota Press, Minneapolis, MN) pp 97-123

McCann E, Ward K, 2011 Mobile Urbanism: Cities and Policy-making in the Global Age (University of Minnesota Press, Minneapolis, MN)

MacFarlane C, 2011, "Assemblage and critical urbanism” City 15 204-224

Machimura T, 2003, "On the corner of diverse/reverse globalization: the third stage of global "urban studies" " International Journal of Urban and Regional Research 27 957-959

MacKenzie D, 2009 Material Markets: How Economic Agents are Constructed (Oxford University Press, Oxford)

MacLeod G, Goodwin M, 1999, "Space, scale and state strategy: rethinking urban and regional governance" Progress in Human Geography 23 503-527 
Massey D, 2011, "A counterhegemonic relationality of place", in Mobile Urbanism: Cities and Policy-making in the Global Age Eds E McCann, K Ward (University of Minnesota Press, Minneapolis, MN) pp 1-14

McNeill D, 2005, "In search of a global architect: the case of Norman Foster (and partners)" International Journal of Urban and Regional Research 29 501-515

MTM, 2005, "Vision 2010 et avenir-Les chantiers", Ministère du Tourisme du Maroc, http://www.tourisme.gov.ma/francais/2-Vision2010-Avenir/2-chantiers/2-Produit/produit.htm

MP, 2009, "Jove apuesta de nuevo por Marruecos con una inversión de 500 millones" $A B C$ (Madrid), 25 September, page 40

Ong A, 2006 Neoliberalism as Exception: Mutations in Citizenship and Sovereignty (Duke University Press, Durham, NC)

Ong A, 2011, "Introduction", in Worlding Cities: Asian Experiments and the Art of Being Global Eds A Roy, A Ong (Wiley-Blackwell, Oxford) pp 1-26

Parker C, 2009, "Tunnel-bypasses and minarets of capitalism: Amman as neoliberal assemblage" Political Geography 28 110-120

Peck J, 2011a, "Creative moments" working culture, through municipal socialism and neoliberal urbanism", in Mobile Urbanism: Cities and Policy-making in the Global Age Eds E McCann, K Ward (University of Minnesota Press, Minneapolis, MN) pp 41-70

Peck J, 2011b, "Recreative city: Amsterdam, vehicular ideas and the adaptive spaces of creativity policy" International Journal of Urban and Regional Research $36462-485$

Peck J, Theodore N, 2010, "Mobilizing policy: models, methods and mutations" Geoforum 41 169-174

Pennell C, 2001 Morocco Since 1830: A History (New York University Press, New York)

Planel S, 2009, "Transformations de l'Etat et politiques territoriales dans le Maroc contemporain" L'Espace Politique 7 1-14

Ren X, 2011 Building Globalization: Transnational Architecture Production in Urban China (University of Chicago Press, Chicago, IL)

Robinson T, 2002, "Global and world cities: a view from off the map" International Journal of Urban and Regional Research 26 531-554

Robinson J, 2011a, "Urban Geography 2010 Plenary Lecture-The travels of urban neoliberalism: taking stock of the internationalization of urban theory" Urban Geography 32 1087-1109

Robinson J, 2011b, "The spaces of circulating knowledge: city strategies and global urban governmentality" in Mobile Urbanism: Cities and Policy-making in the Global Age Eds E McCann, K Ward (University of Minnesota Press, Minneapolis, MN) pp 15-40

Rodríguez, J, 2008, "Jove se fija como meta liderar el sector energético" El País 10 July, http://www.elpais.com/articulo/Galicia/Jove/fija/meta/liderar/sector/energetico/ elpepiautgal/20080710elpgal_9/Tes

Roy A, 2009, “The 21st-century metropolis: new geographies of theory" Regional Studies $\mathbf{4 3}$ $819-830$

Roy A, Ong A, 2011 Worlding Cities: Asian Experiments and the Art of Being Global (Wiley-Blackwell, Oxford)

SMAP IMMO, 2010, "Les médias en parlent", Salon de l'Immobilier Marrocain à Paris, http://www.smapgroup.com/ Les-medias-en-parlent.html?var_recherche=2010

Sassen S, 2001 The Global City: New York, London, Tokyo (Princeton University Press, Princeton, NJ)

Sheller M, Urry J, 2006, "The new mobilities paradigm" Environment and Planning A 38 207-226

Slaoui G, 2009, “Anfaplace, une affaire d'Etat” Le Temps 29 September, http://www.maghress.com/fr/letemps/15182

Soja E, Hooper B, 1993, "The spaces that difference makes: some notes on the geographical margins of the new cultural politics", in Place and the Politics of Identity Eds M Keith, S Pile (Routledge, London) pp 180-202

Stanley B, 2005, "Middle east city networks and the 'new urbanism'" Cities 22 189-199

TMSA, 2010, “About the port” Tanger Mediterranean Special Agency, Tangier

http://www.tmsa.ma/?ld=27\&lang=en 
Taylor P, 2004 World City Network: A Global Urban Analysis (Routledge, London)

Thrift N, 2004, "Transurbanism" Urban Geography 25 724-734

Tsing A, 2005 Friction: An Ethnography of Global Connection (Princeton University Press, Princeton, NJ)

Zaidi N, Chakib M, 1982, "Medina de Tanger: Action d'un tourisme intégré", academic report, Ecole Nationale Supérieure d'architecture de Toulouse, Toulouse

Zemni S, Bogaert K, 2006 "Morocco and the mirages of democracy", discussion paper number 12

(October), Research Unit on International Security and Cooperation, Madrid

Zemni S, Bogaert K, 2009, "Trade, security and neoliberal politics: wither Arab reform?

Evidence from the Moroccan case" Journal of North African Studies 14 91-107 